Modern Asian Studies 52, 3 (2018) pp. 753-783. @ Cambridge University Press 2018 doi:10.1017/Soo26749X17000270

\title{
The Politics of Order and Disturbance: Public authority, sovereignty, and violent contestation in South Asia*
}

\author{
BART KLEM \\ School of Social and Political Sciences, University of Melbourne \\ Email:bklem@unimelb.edu.au \\ BERT SUYKENS \\ Conflict Research Group, Department of Conflict and Development Studies, \\ Ghent University \\ Email:bert.suykens@ugent.be
}

\section{Introduction}

This special issue explores the connections between public authority and violent contestation in a variety of South Asian contexts. Our research is situated in what are often perceived as unruly environments or unruly periods of time, and yet there is often no shortage of rule or purported rulers to be found in this unruliness. In line with an increasing number of scholars, we find it unhelpful to diagnose violent contentions as the failures of state governance or the malfunctioning of democracy. ${ }^{1}$ Instead, we venture to squarely

* Acknowledgements: The authors would like to thank the Modern Asian Studies team, editor-in-chief Joya Chatterji, and editor Norbert Peabody, in charge of this special issue, in particular for their work on the issue. Our co-authors to this special issue have provided valuable feedback to earlier versions of this Introduction. Finally, we want to thank Nel Vandekerckhove who not only provided feedback but was also central in initially formulating the agenda of this special issue.

${ }^{1}$ E. D. Arias and D. M. Goldstein (eds) (2010) Violent democracies in Latin America. Durham: Duke University Press; T. B. Hansen and F. Stepputat (eds) (2005) Sovereign bodies: Citizens, migrants and states in the postcolonial world. Princeton and Oxford: Princeton University Press; C. Lund (2006) 'Twilight institutions: Public authority and local politics in Africa', Development and Change, 37(4), pp. 685-705; J. Spencer (2007) Anthropology, politics, and the state: Democracy and violence in South Asia. Cambridge: Cambridge University Press. 
connect violence to the workings (rather than the lack thereof) of pluriform politics and the state. The central question addressed in this volume is how public authority is constructed in contested political environments. In brief: how do political players craft their legitimacy, reify their constituencies, and forge connections between their subjects and the state-that is, the institutions, resources, and discourses that carry the state's insigne-at times of violent contestation?

Central to this special issue is the conceptual move of combining public authority with the question of (de facto) sovereignty. In doing so we combine the strengths of two useful sets of literature. Scholarly work on public authority is helpful in grappling with questions of performance, patronage, and legitimacy, and with institutions. But it has less to say on questions of antagonism, rupture, violence, and coercion. The second body of literature-on de facto sovereigntyputs these issues at the forefront. It usefully engages with violent rule and the exercise of force and discipline, but its emphasis on violence risks neglecting the hard work that most de facto sovereigns put into legitimizing, rationalizing, and naturalizing their efforts in the formation of public authority.

As the contributions in this volume show, public authority and sovereignty do not necessarily combine. Sovereign forces are not always legitimate and not all holders of public authority have sovereign power. Yet, in many of the contexts studied in this volume there are important connections between the two. As such, conceptually combining these two bodies of literature allows us to better understand the politics of order and disorder in South Asia's contested environments.

Much of the literature on political contestation and violence, both in South Asia and elsewhere, tends to focus either on conflicts 'within' the state (riots, pogroms, mobs, electoral violence) or on conflicts 'against' the state (insurgencies, revolutions, secessionists wars, terrorism). In practice, different kinds of conflict tend to become entangled and the above categories end up becoming rather blurred. Moreover, the divide between conflicts within and against the state carries some problematic normative and political luggage. Endorsing it, in our view, amounts to a mutated form of 'methodological nationalism', ${ }^{2}$ as it

${ }^{2}$ A. Wimmer and N. Glick Schiller (2002) 'Methodological nationalism and beyond: Nation-state building, migration and the social sciences', Global Networks, 2(4), pp. 301-334. 
privileges state rule and sovereignty over other forms; it problematizes some political communities while others are rendered natural; and it legitimizes certain kinds of politics, while 'exceptionalizing' other kinds. The political work that is vested in producing these normative labels and categories should not be hidden from view; rather, it is an intricate part of what public order-making is.

The articles in this volume-each based on extensive fieldwork in different parts of South Asia-cover a wide range of contexts. Some analyse forms of order and legitimacy amid violent insurgencies, others are placed in the context of electoral competition; some are set in peripheral frontiers, others focus on urban university politics. These differences are important and we do not aim to level out this diversity by putting militias and politicians in the same basket or equating Maoist rule with electoral politicking. However, it would be a mistake to make the a priori assumption that the forms of public authority that emerge in these diverse contexts are of a fundamentally different nature. There is in fact remarkable scope for comparison. Let us identify three examples to illustrate this.

One set of issues revolves around the ability of particular actors to (re)formulate rules and enforce them. Martin's article describes how strong-arm politicians in Punjab exert their power over using state resource and the enforcement or waiving of state laws. ${ }^{3}$ Malik discusses how a workers' leader in 1970 s Lahore created his own court to exercise discipline where law enforcement was failing to do so. ${ }^{4}$ And Terpstra and Frerks review the efforts of the Liberation Tigers of Tamil Eelam (LTTE) to co-opt government institutions and create their own surveillance mechanisms in pursuit of a separate state. ${ }^{5}$ Although there are some big differences in these three examples in terms of the actors involved and the context in which they operate, there are also some obvious parallels in their conduct of rule-making.

A second parallel concerns the way in which different kinds of actors use community institutions to access state largesse. Nightingale et al. describe how the Nepalese NGO, FECOFUN gets deeply embroiled

\footnotetext{
${ }^{3}$ N. Martin 'Corruption and factionalism in contemporary Punjab: An ethnographic account from rural Malwa' in this special issue.

${ }^{4}$ A. Malik 'Public authority and local resistance: Abdur Rehman and the industrial workers of Lahore, 1969-1974' in this special issue.

${ }^{5}$ N. Terpstra and G. Frerks 'Governance practices and symbolism: De facto sovereignty and public authority in "Tigerland" in this special issue.
} 
in patronage politics. ${ }^{6}$ Klem and Maunaguru shed light on the way in which the LTTE used village-level development institutions to broker access to state resources. ${ }^{7}$ Byrne's article discusses the tactics of village-level civil servants who deploy established village institutions to sustain themselves as state representatives in the complicated landscape of civil war. ${ }^{8}$ Again, three very different actors-an NGO, a rebel movement, the civil service-but in each case, we see strategic attempts to mobilize non-state entities and community representation in order to tap into the state.

A third set of illustrative parallels revolves around the use of violence. Suykens shows how the violence of student politics does not impede, but in fact bolsters access to state power. ${ }^{9}$ Sen's article on a Calcutta prison discusses the ways in which Naxalite inmates sought to withstand the brutality of licensed excess, and how prisoners' bonds are sustained in this context. ${ }^{10}$ And, finally, Snellinger's work shows us the struggles of Maoist youth in Nepal who strive to make the transition from violent protestors to democratic youth leaders. ${ }^{11}$ In these scenarios, the disparate players are all grappling with paradoxes around violence.

There is thus scope for some fascinating comparative discussions on the conduct of rebels, politicians, union leaders, civil servants, civil society activists, and so on. Of course, there are differences, but it is our contention that it is instructive to think of these as differences of degree, not kind. Reflecting on the parallels between these diverse cases helps unsettling, existing forms of authority to be viewed as inevitable and natural. It informs us about how the rules of the political game are constituted, about crafting exceptions and normalization,

${ }^{6}$ A. J. Nightingale, A. Bhattarai, H. R. Ojha, T. Sigdel and K. N. Rankin 'Fragmented public authority and state un/making in the "new" Republic of Nepal' in this special issue.

${ }^{7}$ B. Klem and S. Maunaguru 'Public authority under sovereign encroachment: Leadership in two villages during Sri Lanka's war' in this special issue.

${ }^{8}$ S. Byrne "From our side rules are followed": Authorizing bureaucracy in Nepal's "permanent transition" in this special issue.

${ }^{9}$ B. Suykens "“A hundred per cent good man cannot do politics": Violent selfsacrifice, student authority, and party-state integration in Bangladesh' in this special issue.

${ }^{10} \mathrm{~A}$. Sen 'Torture and laughter: Naxal insurgency, custodial violence, and inmate resistance in a women's correctional facility in 1970 os Calcutta' in this special issue.

${ }^{11}$ A. Snellinger 'From (violent) protest to policy: Rearticulating authority through the National Youth Policy in post-war Nepal' in this special issue. 
and about the discursive production of legitimate and illegitimate contestation.

There is a vast amount of impressive scholarship on political contestation, violence, and public authority. While we take note of debates in other regions-most saliently in sub-Saharan Africa ${ }^{12}$ and Latin America ${ }^{13}$-we have an explicitly South Asian angle. It is clearly imperative to avoid essentializing South Asian politics, but the region's colonial encounter and subsequent attempts at crafting political collectivities have left a particular mark. We encounter a fine-grained state apparatus and a long-if troubled and at times interrupted-track record of democracy in most of South Asia, and yet it has been riven by violent contestation of virtually every sort. The South Asian literature on politics, violence, and the state is very large indeed. ${ }^{14}$ However, there is surprisingly little that could pass as veritably 'South Asian'-international boundaries run through this literature, almost like epistemic divides. ${ }^{15}$ India's geo-political gravitas has affected academia: the tenets of Indian electoral politics, the rise

${ }^{12}$ T. Hagmann and D. Péclard (2010) 'Negotiating statehood in Africa: Propositions for an alternative approach to state and political authority', Development and Change, 41(4), pp. 539-562; Lund, 'Twilight institutions'; K. Hoffmann and T. Kirk (2013) 'Public authority and the provision of public goods in conflict-affected and transitioning regions', JSRP Paper 7, Justice and Security Research Programme.

${ }^{13}$ Arias and Goldstein, Violent democracies; G. Joseph and D. Nugent (eds) (1994) Everyday forms of state formation: Revolution and the negotiation of rule in modern Mexico. Durham: Duke University Press; D. Nugent (1994) 'Building the state, making the nation: The bases and limits of state centralization in "modern" Peru', American Anthropologist, 96(2), pp. 333-369.

${ }^{14}$ A. Appadurai (2006) Fear of small numbers: An essay on the geography of anger. Durham: Duke University Press; P. Brass (2003) The production of Hindu-Muslim violence in contemporary India. Seattle: University of Washington Press; S. Corbridge, G. Williams, M. Srivastava, and R. Véron (2005) Seeing the state: Governance and governmentality in India. Cambridge and New York: Cambridge University Press; V. Das and D. Poole (eds) (2004) Anthropology in the margins of the state. New Delhi: Oxford University Press; C. Fuller and V. Bénéï (eds) (2009 [2001]) The everyday state and society in modern India. London: Hurst; A. Gupta (1995) 'Blurred boundaries: The discourse of corruption, the culture of politics, and the imagined state', American Ethnologist, 22 (2), pp. 375-402; T. B. Hansen (2001) Wages of violence: Naming and identity in postcolonial Bombay. Princeton and Oxford: Princeton University Press; T. C. Sherman, W. Gould and S. Ansari (2011) 'From subjects to citizens: Society and the everyday state in India and Pakistan, 1947-1970', Modern Asian Studies Special issue, 45(1), pp. 1-6; Spencer, Anthropology, politics, and the state; S. J. Tambiah (2005) 'Urban riots and cricket in South Asia: A postscript to "leveling crowds"”, Modern Asian Studies, 39(4), pp. $897-927$.

${ }^{15}$ For fascinating discussion of circulation, borders, and travelling ideas, see $\mathrm{T}$. Harper and S. S. Amrith (2012) 'Sites of Asian interaction: An introduction', Modern Asian Studies, 46(2), pp. 249-257. 
of Hindu nationalism in recent decades, the violent riots and pogroms associated with it, and fierce debates over secularism are dominant themes in South Asian scholarship. How these developments compare with, or relate to, the political arenas of Bangladesh, Pakistan, Nepal, and Sri Lanka has received much less attention, but there are ample conceptual resources to start addressing this lacuna.

\section{Public authority: the politics of patronage and performance}

Building on Weber's conception of authority as 'legitimate domination', Thomas Sikor and Christian Lund define authority as:

an instance of power that is associated with at least a minimum of voluntary compliance $[\ldots]$. Authority characterizes the capacity of politicolegal institutions, such as states and their constituent institutions, village communities, religious groupings and other organizations, to influence other social actors. ${ }^{16}$

Two observations stand out with regard to this fairly straightforward conceptualization. First, public authority is centrally about legitimacy. It requires a certain amount of buy-in from the 'public' to which authority pertains. That brings us to the second point: it is relational. Public authority harbours vertical mutual connections and is thus tied up with 'the public' and thus with the questions of subjectivity and the public sphere.

The term 'public' also requires some elaboration. ${ }^{17}$ As pointed out by David Gilmartin, ${ }^{18}$ the term 'public' has quite an interesting range of meanings. It may refer directly to the state (public policy), to community standing apart from the state (public opinion), or to the arena between the two (public sphere). In this third meaning, the public sphere refers to a zone of encounter between state and society. Drawing on historical work and legal anthropology on South Asia, Gilmartin posits that it is through this encounter in the public sphere that norms, identities, and forms of rule are worked out. Public

${ }^{16}$ T. Sikor and C. Lund (2009) 'Access and property: A question of power and authority', Development and Change, $40(1)$, p. 8.

${ }^{17}$ See also T. B. Hansen 'Whose public, whose authority? Reflections on the moral force of violence', Afterword in this special issue.

${ }^{18}$ D. Gilmartin (2015) 'Rethinking the public through the lens of sovereignty', South Asia: Journal of South Asian Studies, 38(3), pp. 371-386. See also A. Appadurai and C. A. Breckenridge (1998) 'Why public culture?', Public Culture Bulletin, 1 (1), pp. $5^{-9}$. 
authority pertains both to institutions and to agents, and there is a field of tension between the two. Authority that emanates from an institution is typically embedded in a wider institutional landscape and associated demarcations of constituency, territory, and mandate. Ultimately, many forms of institutional authority refer to the state or forms of state endorsement. Authority figures (i.e. the agent) often derive part of their legitimacy from such an institution, but they have a certain amount of discretionary space, enabling them to enact authority beyond-or even in contradiction to- the designated grasp of institutional prescriptions. Lund points out that although public authority is often 'conjugated' with the state, public authority figures often engage in transgressive behaviour, breaking the law, and undermining the state's coherence. ${ }^{19}$ For some public authority figures, their connection to the state even depends on this ability to break the law, as the case of campus politics in Bangladesh shows. ${ }^{20}$ Lund argues that institutional order does not trickle down from a supreme and coherent state, but emerges from its continuous reproduction in everyday life. ${ }^{21}$

We posit that two forms of practice are pivotal to the generation of authority in the public sphere in South Asia: patronage and performance. In his classic work on agrarian relations in Gujarat, India, Jan Breman has usefully defined patronage as:

a pattern of relationships in which members of hierarchically arranged groups possess mutually recognised, not explicitly stipulated rights and obligations involving mutual aid and preferential treatment. The bond between patron and client is personal, and is contracted and continued by mutual agreement for an indeterminate time. ${ }^{22}$

South Asia's political economy of patronage has been studied quite thoroughly ${ }^{23}$ and, indeed, many South Asians understand the politics

${ }^{19}$ Lund, 'Twilight institutions'.

${ }^{20}$ Suykens in this special issue.

${ }^{21}$ Lund, 'Twilight institutions'. This is illustrated by Byrne's article, which shows how Nepalese bureaucrats use their authority to overstep their jurisdiction: see Byrne in this special issue. Klem and Maunaguru elaborate how public authority may even be projected across the front line between rebels and the state: see Klem and Maunaguru in this special issue.

${ }^{22}$ J. Breman (1974) Patronage and exploitation: Changing agrarian relations in southern Gujarat. Berkeley and Los Angeles: University of California Press.

${ }^{23}$ K. Chandra (2004) Why ethnic parties succeed: Patronage and ethnic head counts in India. Cambridge: Cambridge University Press; Gupta 'Blurred boundaries'; D. Lewis and A. Hossain (2008) Understanding the local power structure in rural Bangladesh. Stockholm: Sida; A. Piliavsky (ed.) Patronage as politics in South Asia. Cambridge: Cambridge University 
around them in terms of money, personal favours, and nepotistic networks. Politics is thus perceived as a dirty and corrupt business. In the words of Arild Engelsen Ruud: 'politicians are viewed as crooks, corrupt and self-seeking, unprincipled and devoid of any ideological commitment'. ${ }^{24}$ And yet, at the same time, there is a clear case to be made that patronage constitutes a form of legitimation, rather than a form of illegitimate power. Partha Chatterjee's notion of 'political society' is insightful here. His conceptual work is inspired by the large numbers of people who live marginal lives as squatters on illegal settlements or work as unauthorized street vendors. ${ }^{25}$ With their outlawed homes and livelihoods, the state-sanctioned channels of 'civil society' are poorly positioned to remedy their plight, so they resort to other 'mediators' (schoolteachers, local politicians, bureaucrats) to bend the rules and make things work for them. It is these networks between the governed and the governing that Chatterjee calls 'political society'. While these ways of accessing state services and resources 'transgress the strict lines of legality', ${ }^{26}$ it is through these practices that a large portion of India's supposed citizenry actually survives. Chatterjee's work, however insightful, calls for a note of caution: the fact that people acknowledge patronage, corruption, wheeling and dealing as part of what has come to be considered 'normal politics' does not mean that they find it acceptable. As Martin's article on Punjab illustrates, people are very aware that the favours granted to them through political networks often do not provide them with firm entitlements, but rather leave them in a precarious position, because such provisions are contingent on their continued political loyalty and their patrons remaining in charge. ${ }^{27}$

While the dynamics of patronage are salient enough in South Asia, recent work in political anthropology argues against a perspective that reduces politics to the shady networks of arranging jobs, material benefits, and licences. In a recent volume devoted to 'patronage as politics', Anastasia Piliavsky and her collaborators argue that looking

Press; P. Ramirez (2000) De la disparation des chefs: Une anthropologie politique népalaise. Paris: CNRS Editions.

${ }^{24}$ A. E. Ruud (2009 [2001]) 'Talking dirty about politics: A view from a Bengali village', in Fuller and Bénéï (eds), The everyday state, pp. $115^{-136}$; here p. 116.

${ }^{25}$ P. Chatterjee (2004) The politics of the governed: Reflections on popular politics in most of the world. New York: Columbia University Press.

${ }^{26}$ Ibid., p. 40.

${ }^{27}$ Martin in this special issue. 
at patronage simply as a 'set of transactions'28 misses the morality ingrained in patronage relations. Here, patrons do not simply appear as greedy and corrupt, but also as munificent leaders, capable of bestowing gifts and providing 'selfless service'. ${ }^{29}$ Drawing on a body of work on political culture, rituals, and symbolism, authors like Mukulika Banerjee and Jonathan Spencer have posited that a purely interest-based understanding of politics is a little 'threadbare', 30 not to say 'intellectually bankrupt'. 31 After all, a purely functionalist perspective on politics is of little help when we try to make sense of the humour and emotions of political gossip; questions of morality, dignity and humiliation; the crowds mesmerized by powerful speeches; the parades of elephants and fancy cars; the idolatry of movie-star politicians; and the dancing, drinking, and intimidation after election victories (to mention some of the examples that Spencer's book discusses). In short, patronage alone does not explain the incredible energy invested in and released by politics.

In his analyses of 'permanent performance' as the basis of Shiv Sena politics in Mumbai, Thomas Hansen states: 'Political performativity comprises [...] the construction of images and spectacles, forms of speech, dress and public behaviour that promotes the identity of a movement or party, defines its members and promotes its cause or

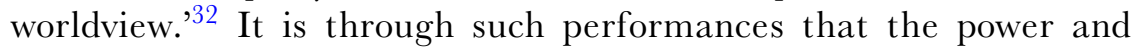
legitimacy vested in public authority are reaffirmed. ${ }^{33}$ As is the case with patronage, the spectacle of political performance does not serve one singular end; it may reify both the authority of the state and of local strongmen or insurgent groups. Competing claims to authority

${ }^{28}$ Piliavsky, 'Introduction', in Piliavsky (ed.), Patronage as politics, p. 21.

${ }^{29}$ Ibid., p. 24.

${ }^{30}$ M. Banerjee (2008) 'Democracy, sacred and everyday: An ethnographic case from India', in J. Paley (ed.) Democracy: Anthropological perspectives. Santa Fe: School of Advanced Research Press, pp. 63-96; here p. 73 .

${ }^{31}$ Spencer, Anthropology, politics, and the state, p. 181.

${ }^{32}$ T. B. Hansen (2004) 'Politics as permanent performance: The production of political authority in the locality', in J. Zavos, A. Wyatt and V. Hewitt (eds) The politics of cultural mobilization in India. New Delhi: Oxford University Press, pp. 19-36; here p. 23 .

${ }^{33}$ B. Klem (2015) 'Showing one's colours: The political work of elections in post-war Sri Lanka', Modern Asian Studies, 49(4), pp. 1091-1121; J. C. Strauss and D. B. Cruise O'Brien (2007) 'Introduction', in J. C. Strauss and D. B. Cruise O'Brien (eds) Staging politics: Power and performance in Asia and Africa. London and New York: I. B. Tauris, pp. 1-14; B. Suykens and A. Islam (2013) 'Hartal as a complex political performance: General strikes and the organisation of (local) power in Bangladesh', Contributions to Indian Sociology, 47(1), pp. 61-83. 
may in fact target the same population and the same territory. And the general repertoire of the state's authority often overlaps with more particular forms of public authority.

Piliavsky posits that patronage is anchored in 'relational morality: a set of ideas about how those who govern and those they govern should relate to each other $[\ldots],{ }^{34}$ The performance of authority is embedded in such a set of ideas, as several contributions to this special issue show. For example, the iconography of sacrifice in Bangladeshi student politics constitutes a citational practice of culturally coded historical repertoires of violent martyrdom. ${ }^{35}$ Political youth leaders in Nepal deploy particular kinds of speech to stress and produce their authority during bureaucratic meetings. ${ }^{36}$ Similarly, the conduct of Nepalese civil servants evinces a level of continuity of what are seen as acceptable forms and norms throughout the convoluted landscape of war and a long sequence of historical transitions. ${ }^{37}$ Sometimes, these implied cultural norms preserve boundaries that curtail the crude force of domination. Klem and Maunaguru discuss the example of a Hindu priest who draws on the authority of a goddess and the protected space of her temple to withstand the LTTE. ${ }^{38}$ Public authority is thus produced through the performance of established repertoires, registers, or cultural codes, but it also improvises and transforms these registers.

Performance and patronage thus bring forward different dimensions of politics, but it would be a mistake to treat them as oppositional perspectives. The workings of patronage and performance are often closely related. And, indeed, public authority acts as the binding concept between these two elements of South Asian politics. Patronage is not just about resources: deriving public authority from such resources involves dramatizing their significance and taking credit for it. Vice versa, the performance of electoral scripts (speeches, rallies, canvassing) or bureaucratic power often does not only involve symbols, rhetoric, and staged appearances; the ability to make a material difference boosts the political potency of such performances. Failure to deliver can turn a local strongman into a subject of laughter

\footnotetext{
${ }^{34}$ Piliavsky, 'Introduction', p. 28.

${ }^{35}$ Suykens in this special issue.

${ }^{36}$ Snellinger in this special issue.

${ }^{37}$ Byrne in this special issue; Nightingale et al. in this special issue.

${ }^{38} \mathrm{Klem}$ and Maunaguru in this special issue.
} 
and humiliation, and such a change of fortune can take place rather quickly. ${ }^{39}$

\section{The difficulty of studying the everyday state}

The set of institutions, resources, and discourse that we designate 'the state' has resurfaced as a fertile subject of study over the past decade. The need to steer away from classical textbook conceptualizations of the state as a formalized political order-which is separate from society and endowed with a monopoly of legitimate violence-has become well-established both in South $\mathrm{Asia}^{40}$ and elsewhere. ${ }^{41}$ The state does not simply hang above the fray, adjudicating the tussles and struggles in society, it is entangled with those contentions. Neither can the state be seen as an actor, a coherent agent that operates strategically in society. The apparent naturalness of the state, its aura of indispensability, and the myth of its rational and legitimate nature do not explain what the state is; rather, these are the odd things that beg for an explanation. How are state institutions and practices rendered natural, indispensable, and legitimate? How is it that people transform into citizens and subjects of a state that typically fails to live up to their expectations? How is it that the discursive and material boundaries between state and society are reproduced by the same acts that expose their arbitrariness: people putting on uniforms or taking them off, the moulding of practices into rational order, and the

${ }^{39}$ Ruud, 'Talking dirty'.

${ }^{40}$ Das and Poole, Anthropology in the margins; C. Fuller and J. Harriss (2009 [2001]) 'For an anthropology of the modern Indian state', in Fuller and Bénéi (eds), The everyday state, pp. 1-30; D. N. Gellner (ed.) (2007) Resistance and the state: Nepalese experiences. New York and Oxford: Berghahn Books; Gupta, 'Blurred boundaries'; A. Gupta (2012) Red tape: Bureaucracy, structural violence, and poverty in India. Durham and London: Duke University Press; B. Klem (2012) 'In the eye of the storm: Sri Lanka's front-line civil servants in transition', Development and Change, 43(3), pp. 695-717; Sherman et al., 'From subject to citizens'; Spencer, Anthropology, politics, and the state; N. Vandekerckhove (2011) 'The state, the rebel and the chief: Public authority and land disputes in Assam, India', Development and Change, 42(3), pp. 759-779.

${ }^{41}$ P. Abrams (1988 [1977]) 'Notes on the difficulty of studying the state', Journal of Historical Sociology, 1(1), pp. 58-89; Hagmann and Péclard, 'Negotiating statehood in Africa'; T. M. Li (2005) 'Beyond "the state" and failed schemes', American Anthropologist, $107(3)$, pp. 383-394; T. Mitchell (1991) 'The limits of the state: Beyond statist approaches and their critics', American Political Science Review, 85(1), pp. 77-96; J. Putzel and J. Di John (2012) 'Meeting the challenges of crisis states', Crisis States Research Centre Report, London School of Economics and Political Science. 
continuous endorsement and appropriation with stamps, labels, and forms?

Scholarly engagement with these questions has spawned a rather elaborate lexicon-statehood, stateness, quasi-states, stategraphy, and associated concepts - to deflect the criticism of conceiving of 'the state' as something essential or monolithic. However, many of these terms have ended up rather quickly in the already overcrowded graveyard of academic neologisms. ${ }^{42}$ Instead of coining a new set of short-lived prefixes or suffixes, we consider it acceptable to use 'the state' as shorthand for the institutions, resources, and discourses that carry the state insigne, with different articles in the special issue highlighting case-specific conceptualizations of the state. ${ }^{43}$ Using more specific terms when possible seems more sensible to us than replacing one grand concept with another one.

Philip Abrams' neo-Marxist essay on the difficulties of studying the state is foundational to contemporary studies on the abovementioned questions. ${ }^{44}$ Rather than endeavouring to discover the reality behind the state facade (the supposed core of order, regulation, and welfare distribution), Abrams famously argued that this facade is all there is. More than anything else, the state is an ideological project, and academics ought to question how and why this facade comes into being. Roughly in line with this argument, Timothy Mitchell posits that instead of a form of order that guides practices, the state can best be seen as a structural effect of those practices. ${ }^{45}$

Rather than being a self-evident grid of hierarchy and categorization, a canvas that organizes society, the state thus becomes contingent on and emergent from everyday practices. An earlier special issue of this journal explored the workings of the post-colonial state in India and Pakistan from this perspective to shed light on how state performances and associated subjectivities unfolded around independence. ${ }^{46}$ Taking issue with radical breaks between countries (India and Pakistan) and eras (before and after independence), the contributors to that issue underscore that notions of citizenship and bureaucratic functioning were far less settled in everyday

\footnotetext{
${ }^{42}$ Others have simply resorted to 'state' as a generic noun (i.e. 'state' rather than 'the state'), but this leads to somewhat unusual grammar and we do not think that leaving out the article solves the problem.

${ }^{43}$ See, for example, Byrne in this special issue; Nightingale et al. in this special issue; Suykens in this special issue.

${ }^{44}$ Abrams, 'Notes on the difficulty'.

${ }^{45}$ Mitchell, 'The limits of the state'.

${ }^{46}$ Sherman et al., 'From subject to citizens'.
} 
life than established historical interpretations suggest. On a more contemporary note, Hansen and Stepputat explore how the state 'tries to make itself real and tangible through symbols, texts, and iconography'. ${ }^{47}$ They argue that we should regard 'the rhetoric of state officials, the nicely crafted white papers and policy documents, the ostensibly scientific forms of governance, the grand schemes and organizational efforts of governments, with all their paraphernalia of vehicles, titles, and little rituals, as parts of a continuous state spectacle asserting and affirming the authority of the state'. ${ }^{48}$ The boundary between state and society remains evanescent, though, and many non-state actors resort to very similar strategies. ${ }^{49}$

Yet, despite its blurred boundaries and kaleidoscopic qualities, the state is very present in people's lives, as Chris Fuller and John Harriss's introduction to an edited volume on the 'everyday state' in India underlines. ${ }^{50}$ 'Sarkar', the vernacular term in big parts of South Asia which encompasses both state and government, appears on many levels and in many centres. And the boundaries with its supposed 'other'-society—are fluid and negotiable, according to social context and position. Yet, despite these embroilments, Fuller and Harriss argue that the state retains its importance. Impersonal norms, secular government, and rational bureaucracy may be a mythical facade, but they do form part of people's expectations, despite all the transgression that they themselves are involved in. The boundaries may be blurred, but they are nonetheless perceived as boundaries. The state remains central to political imagination in South Asia, and all the debate on resistance sits uneasily alongside the fact that people all over the region tend to try and engage with state institutions for their own benefit, rather than resist them. ${ }^{51}$

${ }^{47}$ T. B. Hansen and F. Stepputat (2001) 'Introduction: States of imagination', in T. B. Hansen and F. Stepputat (eds) States of imagination: Ethnographic explorations of the postcolonial state. Durham and London: Duke University Press, pp. 1-4o; here p. 5 .

${ }^{48}$ Ibid., p. 27.

${ }^{49}$ In fact, it is not uncommon for non-state forms of order and service delivery to be more efficient that those of the state. For an interesting example, see the discussions on kinship networks and self-organization among refugees in the $195^{\circ}$ os and 1960s: J. Chatterji (2007) "Dispersal” and the failure of rehabilitation: Refugee camp-dwellers and squatters in West Bengal', Modern Asian Studies, 41(5), pp. 995-1032; W. Gould (2011) 'From subjects to citizens? Rationing, refugees and the publicity of corruption over Independence in UP', Modern Asian Studies Special issue, 45(1), pp. 33-56.

${ }^{50}$ Fuller and Harriss, 'For an anthropology'.

${ }^{51}$ Ibid. See the chapters in Fuller and Bénéi (eds), The everyday state. See also Corbridge et al. Seeing the state. 
Public authority has a paradoxical relationship with the state. As mentioned above, public authority is often derived from representing state institutions, securing access to state resources, and confirming the state's discourses of order and legitimacy, but it may also stem from the ability to withstand the state, to transgress or bend state rules, to unleash trouble and run amok. It may comprise dignity and righteousness, but it may also emerge from the cunning and boldheadedness that is required to operate in South Asia's treacherous political landscape. The deployment of violence is prone to similar paradoxes. Das and Poole put the spotlight on the production of the division between state (legitimate) and non-state (illegitimate) violence: 'In this vision of political life, the state is imagined as an always incomplete project that must constantly be spoken ofand imagined-through an invocation of the wilderness, lawlessness, and savagery that not only lies outside its jurisdiction, but also threatens it from within. ${ }^{52}$ They discuss the role of local strongmen, paramilitaries, and powerful economic players: 'Such figures of local authority represent both highly personalized forms of private power and the supposedly impersonal or neutral authority of the state. It is precisely because they also act as representatives of the state that they are able to move across-and thus muddy - the seemingly clear divide separating legal and extra-legal forms of punishment and enforcement. ${ }^{53}$ Public authority and violence may thus be deployed to bolster both state rule and more particularistic, transgressive agendas. And they may be underpinned by the ability to tap into state institutions, but also by the ability to withstand them.

\section{Violence and de facto sovereignty}

Public authority breeds not only within (state) order, but in disturbance as well. It is here that we find Jonathan Spencer's exposé on 'anthropology, politics and the state' in South Asia particularly insightful. ${ }^{54}$ Spencer argues that the unruliness of South Asian politics-its unsavoury potential to split people, precipitate trouble,

\footnotetext{
${ }^{52}$ Das and Poole, Anthropology in the margins, p. 7.

${ }^{53}$ Ibid., p. 14 .

${ }^{54}$ Spencer, Anthropology, politics, and the state. Spencer draws on 'radical democracy' scholars like Chantal Mouffe, who in turn revisits the work of the German political theorist Carl Schmitt.
} 
and invoke violence-is not a problematic side-effect of politics nor a sign of its failure to replicate European Enlightenment and liberalism. Rather, the co-creation of friends and foes, the antagonism between us and them, is foundational to what politics is, everywhere, not least in South Asia. ${ }^{55}$ And, in a similar vein, 'collective violence should not be treated as a departure from the flow of the political, but should rather be analysed as a heightened and intensified continuation of normal politics'. ${ }^{56}$ That brings us to the next step in our analysis: to connect public authority to questions of contestation and violence. Literature on public authority often remains mute on this connection to violence and coercion. Lund's work on sub-Sahara Africa, ${ }^{57}$ for example, provides an otherwise stimulating and quite encompassing discussion of public authority, but it does not really explore the relationship between violence and public authority. This is strange, given all the talk of transgression and irregularity, and the fact that (violent) contestation abounds in the countries concerned. For the contexts that we study, a conceptualization of public authority that steers clear of questions of conflict and violence would be a little too smooth. This special issue thus aims to complement this literature by exploring the interconnections between violence and public authority.

This connection is somewhat paradoxical. It seems common sense that violence undermines or unmasks public authority. After all, public authority pivots on legitimacy and acceptance. The deployment of violence thus indicates that something is not quite right with the authorities in place, particularly when violence is used against the people who supposedly fall within the purview of those authorities. For example, Sen's gripping account of Naxalite inmates suggests that when prison guards deploy cruel and excessive violence on political prisoners, this may undermine the authority of state institutions. ${ }^{58}$ But the reverse is possible too, other contributions to the special issue show. The ability to deploy violence, to punish, to protect, or just to be someone to reckon with can bolster public authority. And the preparedness to undergo the danger and suffering associated with violence can be an enigmatic source of political charisma. ${ }^{59}$ This puzzling relationship between violence and public authority stands

\footnotetext{
${ }^{55}$ See, for example, Tambiah, 'Urban riots and cricket'.

${ }^{56}$ Ibid., p. 120.

${ }^{57}$ Lund, 'Twilight institutions'.

${ }^{58} \mathrm{Sen}$ in this special issue.

${ }^{59}$ Suykens in this special issue.
} 
at the heart of this special issue. We seek to disentangle this puzzle by connecting our central concept—public authority—to the analytical angle of 'de facto sovereignty'.

Hansen and Stepputat coined this term to argue against the canonical understanding of sovereignty, which portrays the sovereign state as the bedrock of a civilized international order. ${ }^{60}$ They detach sovereignty from its necessary link to the state and direct our attention to the practices of sovereignty. They define de facto sovereignty as 'the ability to kill, punish, and discipline with impunity'. ${ }^{61}$ The state has no self-evident monopoly on this ability, they underline. Rather, state sovereignty is a peculiar and contingent form of sovereignty.

Hansen and Stepputat usefully connect some of the high prose on sovereign power (their intellectual pedigree includes political theorists like Carl Schmitt, Georges Bataille, Michel Foucault, and Giorgio Agamben) to the messy everyday realities of ethnography. Their conceptualization of de facto sovereignty provides a helpful perspective to differentiate between a wide variety of political groupings that rely on (the threat of) violence. It offsets the normative schemata of legal/illegal, democratic/undemocratic, and state/nonstate, which are clearly not entirely irrelevant, but often obscure as much as they elucidate. After all, in the contested environments that we study, the amalgam of state, legality, and democracy provides no solid conceptual base. These concepts typically stand at the heart of the problem. De facto sovereignty opens up space to grapple with public authority's paradoxical relationship with violence, by thinking of de facto sovereignty as an especially encompassing form of public authority in which the legitimate exercise of power ultimately encompasses the capacity to kill with impunity. The differentiation between distinct forms of public authority-depending on the ability to instil order by deploying violence and get away with it- then enables us to address some of the problems of methodological nationalism. It sheds some of the normative luggage of dividing the world into natural, legitimate states, on the one hand, and transgressive, disruptive violent groups, on the other.

Rather than taking states as the norm and groups like Shiv Sena, the Naxalites, Nepal's Maoists, or the Liberation Tigers of Tamil Eelam as exceptional phenomena that need to be explained and addressed,

${ }^{60}$ T. B. Hansen and F. Stepputat (2006) 'Sovereignty revisited', Annual Review of Anthropology, 35, pp. 295-315.

${ }^{61}$ Ibid., p. 296. 
we could approach such armed groups as sovereign articulations in their own right. Many armed political outfits mimic the state. They emulate dominant orders, reproduce structures of governance, and adopt state-like terminology to further their cause. But in doing so, they also tweak and transform the registers that they are adopting. ${ }^{62}$ While the deployment of strategic and disciplinary violence is centrally important ${ }^{63}$ there is more to rebel projects than political order. It would be overly mechanical to boil rebel governance down to a cold project of coercion paired with a rational calculus of people accepting extortion/tax, duress/rules, and abduction/recruitment in exchange for protection (and the promise of welfare and representation). There is something more awe-inspiring about sovereign power. While violence and discipline are essential, armed movements are also about political affinities, cultural ties, and mythical cults of heroism and martyrdom.

Some of the seminal philosophical work on sovereignty suggests that there is a mythical, theological dimension to sovereignty. It is not simply an extreme form of power that emerges from within a community. Sovereignty draws from registers beyond the reach of that community, typically from a spiritual space that cannot be fully fathomed or tamed. In the European tradition, this is perhaps best captured by Kantorowicz's classic work on the Christian antecedents of medieval kingship. ${ }^{64}$ In the South Asian context, Heesterman's work on political orders in pre-Islamic India makes similar observations. He discusses the way kings are connected to the jungle, to a space beyond the moral order of community, in which spirits reign. ${ }^{65}$ This may seem a bit of a detour, but this perspective highlights the irresolvable paradox at the heart of sovereignty. David Gilmartin's work discusses

\footnotetext{
${ }^{62}$ For a more thorough elaboration of this argument of sovereignty as citational practice, see B. Klem and S. Maunaguru (2017) 'Insurgent rule as sovereign mimicry and mutation: Governance, kingship and violence in civil wars', Comparative Studies in Society and History, 59(3), pp. 629-656.

${ }^{63}$ See the literature on rebel governance: A. Arjona (2014) 'Wartime institutions: A research agenda', Journal of Conflict Resolution, 58, pp. 1390-1418; A. Arjona, N. Kasfir and Z. Mampilly (2015) (eds) Rebel governance in civil war. Cambridge: Cambridge University Press; P. Staniland (2012) 'Organizing insurgency: Networks, resources and rebellion in South Asia', International Security, 37(1), pp. 142-177; J. Weinstein (2007) Inside rebellion: The politics of insurgent violence. Cambridge: Cambridge University Press.

${ }^{64}$ E. Kantorowicz (1997 [1957]) The king's two bodies: A study in mediaeval political theology. Princeton: Princeton University Press.

${ }^{65} \mathrm{~J}$. C. Heesterman (1985) The inner conflict of tradition: Essays in Indian ritual, kingship and society. Chicago: University of Chicago Press.
} 
this most clearly. Sovereigns, he underlines, need 'to be effective agents of order (and governance) in the mundane political world (and thus to be effectively engaged with all the community's conflicts and divisions)'. Yet, at the same time they also need to 'transcend all society's conflicts and divisions, standing apart from them and embodying the community (and the polity) as a unity'. ${ }^{66}$ In short, sovereignty has to be both part of society and external to it: it has to be both interested and disinterested.

De facto sovereignty thus involves rather more than projecting a regime of rules and enforcing them with violent discipline. It is a more encompassing intervention in the public sphere and involves a more fundamental rearticulation of community. It taps into cultural registers of belonging, genealogy, divinity, and legitimacy. Some armed groups in South Asia managed this in quite successful ways, at least for some time. They succeeded in naturalizing themselves as rulers of a redefined constituency, while destabilizing the indispensability, legitimacy, and taken-for-granted nature of the state and its demarcated notions of nation and territory. This moves our attention to questions about the political work that goes into categorizing different projects of rule and the political effects they have. While Hansen and Stepputat's definition of de facto sovereignty captures a crucial element of that process-the ability to enforce discipline with impunity - the focus on violence should not obfuscate related questions of legitimacy and subjectivity. ${ }^{67}$

This then brings us back to the question of public authority. The concept provides an anchor point for questions of legitimacy in the scholarship on de facto sovereignty, a field that is so fascinated by violence that it occasionally appears to be at risk of neglecting the hard work that pretty much all de facto sovereigns invest in presenting their ruthless practices as necessary and defendable in service of a greater cause. Public authority's two main components-patronage and performance-thus re-enter the limelight. While their ability to provide prosperity is often very limited, some armed movements try quite hard to manipulate the channelling of resources and take credit for it. And they invest a remarkable amount of energy in the performance of sovereignty, with parades, ceremonies, flags, hymns, propaganda, uniforms, offices, and forms, but also with cults

${ }^{66}$ Gilmartin, 'Rethinking the public', p. 373 .

${ }^{67}$ This become particularly clear in the articles by Klem and Maunaguru, and Terpstra and Frerks, both in this special issue. 
of martyrdom, heroism, divine endorsement, and so on. This then enables us to draw parallels between these armed movements and less sovereign public authority figures, who engage in very similar practices of patronage and performance to support and build their authority.

\section{South Asia's diverse political landscape: differences of degree, not kind?}

The combination of public authority and de facto sovereignty opens up space to think of a wide range of violent claimants to political rule from a similar vantage point. It enables us to engage both with the question of violence and discipline (emphasized in the literature on sovereign power) and with the ways in which these forms of power are rationalized, legitimized, and naturalized (explored in the literature on public authority). It also sheds light on the way non-sovereign public authority figures (who do not aspire to or are unable to exercise discipline with impunity) manage their relations with de facto sovereigns. The articles in this volume explore the operation of public authority in a wide range of violent contexts in South Asia. Approaching these diverse contexts from a similar vantage point is important, because it helps us to grapple with some of the problematic categorical boundaries that have divided South Asian scholarship with regard to political order, contestation, and violence. There is, for example, an impressive body of work on insurgencies and civil war in South Asia. ${ }^{68}$ This scholarship seems to

${ }^{68}$ S. Baruah (2007) Durable disorder: Understanding the politics of Northeast India. New Delhi: Oxford University Press; A. Blom (2009) 'A patron-client perspective on militia-state relations: The case of Hizb-ul-Mujahidin of Kashmir', in L. Gayer and C. Jaffrelot (eds) Armed militias of South Asia: Fundamentalists, Maoists, and separatists. New York: Columbia University Press, pp. 135-1 $5^{8}$; Gayer and Jaffrelot (eds), Armed militias of South Asia; D. Hughes (2013) Violence, torture and memory in Sri Lanka. London: Routledge; B. Korf (2004) 'War, livelihoods and vulnerability in Sri Lanka', Development and Change, 35(2), pp. 275-295; M. Lawoti and A. K. Pahari (eds) (2010) The Maoist insurgency in Nepal: Revolution in the twenty-first century. Oxford: Routledge; M. Lecomte-Tilouine (2010) 'Political change and cultural revolution in a Maoist model village, mid-western Nepal', in Lawoti and Pahari (eds), The Maoist insurgency in Nepal, pp. 115-132; L. Onesto (2005) Dispatches from the People's War in Nepal. London: Pluto Press; Z. Mampilly (2011) Rebel rulers, insurgent governance and civilian life during war. Ithaca: Cornell University Press; A. Mohsin (2003) The Chittagong Hill Tracts, Bangladesh: On the difficult road to peace. Boulder and London: Lynne Rienner Publishers; A. Shah (2010) In the shadowes of the state: Indigenous politics, environmentalism 
be almost entirely disconnected from an equally impressive body of work on muscle politics, thuggery, communal violence, and riots. ${ }^{69}$ A third academic arena within South Asian scholarship focuses on the state: its imaginary image of coherence and unity, the everyday practices at loggerheads with this, and the convoluted practices of state institutions like the civil service in grappling with the contradictions at stake. ${ }^{70}$

and insurgency in Jharkhand, India. Durham and London: Duke University Press; A. Shah and J. Pettigrew (2009) 'Windows into a revolution: Ethnographies of Maoism in South Asia', Dialectical Anthropology, 33(3), pp. 225-251; B. Suykens (2010) 'Diffuse authority in the Beedi commodity chain: Naxalite and state governance in tribal Telangana, India', Development and Change, 41(1), 153-178; S. Thiranagama (2011) In my mother's house: Civil war in Sri Lanka. Philadelphia: University of Pennsylvania Press; N. Vandekerckhove and B. Suykens (2008) "The liberation of Bodoland": Tea, forestry and tribal entrapment in Western Assam', South Asia: Journal of South Asian Studies, 31(3), pp. 450-471.

${ }^{69} \mathrm{~W}$. Berenschot (2011) Riot politics: Hindu Muslim violence and the Indian state. London: Hurst; Brass, The production of Hindu-Muslim violence; V. Das (2007) Life and words: Violence and the descent into the ordinary. Berkeley, Los Angeles and London: University of California Press; L. Michelutti (2010) 'Wrestling with (body) politics: Understanding muscular political styles in North India', in Pamela Price and Arild Ruud (eds) Power and influence in South Asia: Bosses, lords, and captains. Delhi, London: Routledge, pp. 44-69; N. Peabody (2009) 'Disciplining the body, disciplining the bodypolitic: Physical culture and social violence among North Indian wrestlers', Comparative Studies in Society and History, $5^{1}$ (2), pp. 272-400; O. Shani (2005) 'The rise of Hindu nationalism in India: The case study of Ahmedabad in the 1980s', Modern Asian Studies, $39(4)$, pp. 861-896; H. Spodek (2010) 'In the Hindutva laboratory: Pogroms and politics in Gujarat, 2002', Modern Asian Studies, 44(2), pp. 349-399; Tambiah, 'Urban riots and cricket'; O. Verkaaik (2004) Migrants and militants: Fun and urban violence in Pakistan. Princeton: Princeton University Press.

${ }^{70}$ Das and Poole, Anthropology in the margins; Fuller and Bénéi, The everyday state; Gellner, Resistance and the state; Gupta, 'Blurred boundaries'; Gupta, Red tape; T. B. Hansen (2009 [2001]) 'Governance and myth of state in Mumbai', in Fuller and Bénéï (eds), The everyday state, pp. 31-67; S. Hossain (2011) 'Informal dynamics of a public utility: Rationality of the scene behind a screen', Habitat International, 35(2), pp. 275-285; Klem, 'In the eye of the storm'; A. Krishna (2011) 'Gaining access to public services and the democratic state in India: Institutions in the middle', Studies in Comparative International Development, 46(1), pp. 98-117; J. Manor (2000) 'Small-time political fixers in India's states: "Towel over armpit", Asian Survey, 4o(5), pp. 816-835; A. Nightingale and H. Ojha (2013) 'Rethinking power and authority: Symbolic violence and subjectivity in Nepal's terai forests', Development and Change, 44(1), pp. 29-51; J. Pfaff-Czarnecka (2008) 'Distributional coalitions in Nepal: An essay on democratization, capture, and (lack of) confidence', in D. N. Gellner and K. Hachhethu (eds) Local democracy in South Asia: Microprocesses of democratization in Nepal and its neighbours. Delhi: Sage, pp. 71-104; Price and Ruud (eds), Power and influence in India; Ramirez, De la disparation des chefs; G. R. Reddy and G. Haragopal (1985) 'The pyraveekar: "The fixer" in rural India', Asian Survey, 25(11), pp. 1148-1162. 
This special issue seeks to bring these three bodies of work into dialogue with each other. Rather than treating guerrillas, goondas, politicians, and civil servants as fundamentally different kinds of actors, we posit that it is helpful to think of all these actors as public authority figures. While their objectives, abilities, and strategies differ, there is no reason to categorize them a priori as fundamentally different kinds of players. The dividing line between sovereign and non-sovereign forms of public authority is inherently unstable. It is very common for the state (or other sovereign forms of public authority) to depend on proxies (non-sovereign forms of authority) to consolidate and legitimize their rule, and vice versa, for authority figures like civil servants or politicians to derive part of their legitimacy from their linkages to the sovereign state. These blurred boundaries may shift over time. Particularly in regions undergoing intense transition, like parts of post-war Nepal and Sri Lanka in recent years, many actors have had to rearticulate their authority, as different projects of sovereignty waxed and waned. ${ }^{71}$

How, then, do we approach these diverse actors in a way that does not put them in rigid boxes on the basis of face-value judgements, but at the same time does not simply suggest they are all one and the same? In an attempt to find more sensible ways of exploring difference and change, we posit that three entry points are particularly helpful: the deployment of violence, the crafting of territory and subjectivity, and the relationship with the state. These three heuristic lines of inquiry enable us to differentiate between more-or-less sovereign forms of public authority, without removing from the equation the ambiguities and complexities on the ground.

The first entry point-violence-links directly to Hansen and Stepputat's work on de facto sovereignty. Public authority develops sovereign qualities when it involves the deployment of violence with impunity. Disciplinary violence is central here. Most obviously, this involves law enforcement by the state, which is outsourced in legal or not-so-legal ways to specific entities. This often creates spaces of licensed excess where violence specialists craft regimes that may well be at odds with the purported foundations of order and authority of these entities: prison guards engage in brutalities, ${ }^{72}$ well-connected politicians engineer fabricated charges to intimidate

\footnotetext{
${ }^{71}$ Nightingale et al. in this special issue; Snellinger in this special issue.

${ }^{72} \mathrm{Sen}$ in this special issue.
} 
potential challengers into loyalty. ${ }^{73}$ Malik's work in this issue shows that judiciary experiments, which are partly steeped in state institutions, may take on a life of their own. Abdur Rehman's workers' court in the conflict-ridden Lahore of the 1970s complemented law enforcement and pressured the police to their job, but also projected forms of discipline that escaped the ambit of state law. ${ }^{74}$

Elsewhere in South Asia we find movements that took such initiatives to a more encompassing level. The Nepalese Maoists, the LTTE, and the Naxalites craft(ed) an elaborate disciplinary regime that defied correction by the state. It is not because they managed to evade such a correction, but because they stabilized their rule to such an extent that in fact it went unchallenged, at least for some time. They did not rely on the state machinery turning a blind eye or setting other priorities. These movements constructed an institutional facade of inevitability and legitimacy (self-declared police officers, courts, customs, tax administration), corroborated with an ideology around their disciplinary regime. ${ }^{75}$ In Sri Lanka, the LTTE built an extensive governance framework and, as a result, their enforcement regime did not always require open violence. ${ }^{76}$ Alongside disciplinary violence, some of the actors we study, engage in wholly hostile violence. As the literature on rioting shows, the targeting of enemies often serves to harden boundaries, accentuate particular differences, and thus restrain the in-group (vivisectionist violence, to speak with Appadurai ${ }^{77}$ ). Such efforts may develop sovereign qualities when tactical violence, which makes people show their colours, evolves into enduring and unimpeded deterrence of particular groups, for example through systematic pogroms of ethnic cleansing.

Yet, these violent practices do not stand alone; they are typically backed up by non-violent performance of public authority. As Pamela Price and Arild Ruud have argued in their introduction to a volume

${ }^{73}$ Martin in this special issue.

${ }^{74}$ Malik in this special issue.

${ }^{75}$ M. Lecomte-Tilouine (ed.) (2013) Revolution in Nepal: An anthropological and historical approach to the People's War. Delhi: Oxford University Press; K. Ogura (2008) 'Maoist people's governments 2001-2005: The power in wartime', in Gellner and Hachhethu (eds), Local democracy in South Asia, pp. 175-231; Thiranagama, In my mother's house.

${ }^{76}$ Terpstra and Frerks in this special issue. This notwithstanding, coercion and brutal forms of discipline obviously existed side-by-side with these governance institutions.

${ }^{77}$ Appadurai, Fear of small numbers. 
on political leadership in South Asia, violence is only one avenue by which to build leadership and (political) authority. ${ }^{78}$ For nonsovereign public authority figures, both forms of violence (disciplinary and hostile) provide a challenge. As Byrne's work on state bureaucrats during the Nepal civil war suggests, ${ }^{79}$ these public authority figures have to rely on covert tactics and highly constrained theatres of operation to uphold some authority, and they become implicated in de facto sovereign projects. They can become part of an (administrative) apparatus that helps to naturalize sovereignty projects (as was the case with the village development committees discussed by Klem and Maunaguru ${ }^{80}$ ).

A second entry point for investigating the relation between sovereignty and public authority comprises the ability to craft territory and subjectivity. All public authority figures nurture spaces of power and constituencies to which their authority pertains. Bureaucrats have their fields of competence and they often spend a fair amount of energy preserving the boundaries around who or what falls within their purview-or not. They can become small-time fiefs in the territory under their jurisdiction. When we move across the spectrum, we find the town- or neighbourhood-based big men that characterize much of South Asia's political landscape. They often have a fairly clear turf. Their vote bank needs to have some spatial concentration to make electoral sense. Block votes of caste, ethnic, or religious groups are mobilized by deploying the tentacles of the state in their neighbourhoods: resources flow (e.g. land titles, infrastructure), enforcement regimes are suspended (e.g. turning a blind eye to the theft of electricity of water), and favours are provided (jobs, licences). ${ }^{81}$ The constituency serviced by such patronage is typically made visible during election time. The performance of rallying and canvassing then seeks to dramatize the unity of the community, the ties to their leader, and the long-standing record of his (or her) family in the area. Such projects of subject- and territory-making are typically compatible with the larger composite of the state and the nation.

In this regard, these forms of territorialization and subject formation are quite different from more sovereign forms of political authority. Some insurgent movements with sovereign ambitions make

\footnotetext{
${ }^{78}$ Price and Ruud, Power and influence in India, p. xxix.

${ }^{79}$ Byrne in this special issue.

${ }^{80} \mathrm{Klem}$ and Maunaguru in this special issue.

${ }^{81}$ Martin in this special issue.
} 
great efforts to turn the people they claim to rule into loyal taxpaying citizens, into members of a nascent ethnic nation (in the case of ethnoseparatists), devout subjects (fundamentalists), or workingclass labourers and peasants (revolutionaries). Their efforts are thus more encompassing than those of the politicians discussed above: they explicitly try to sever their subjects from the state. They enact their political agenda through institutions created on their terms. Such insurgent strategies often place higher demands on their subjects and their territories are more consolidated. In northeastern Sri Lanka, the LTTE controlled large swathes of territory, marked by checkpoints, flags, memorial sites, and a whole range of LTTE offices for civil administration. ${ }^{82}$ And yet, rebel rule never completely erased competing forms of territoriality: Sri Lankan government institutions continued to function, if in a compromised way, in these same areas. ${ }^{83}$ Similarly, Nepalese civil servants continued to distribute some state resources in areas under Maoist control. ${ }^{84}$ The 'liberated zones' of India's Naxalites are interspersed among the territorialization and subject formation of the Indian state. ${ }^{85}$ And Abdur Rehman's court in Lahore (mentioned above) was embedded in a landscape of factories and workers' quarters which coexisted with the administrative geography of the Pakistani state. ${ }^{86}$

The third entry point concerns an actor's relationship with the state. At first sight, de facto sovereignty and relations with the state seem inversely related properties. Rebels openly fight against the state, while political outfits with no sovereign ambitions are typically closely entangled with the state. The latter crucially rely on their connection with the state to provide patronage and dispense benefits to their constituency, while the raison d'être of the former is to resist state rule. That is too simple a characterization, however. In fact, all of the actors

${ }^{82}$ Klem and Maunaguru, 'Insurgent rule'; Klem and Maunaguru in this special issue; Terpstra and Frerks in this special issue.

${ }^{83}$ Klem, 'In the eye of the storm'; B. Korf, M. Engeler, T. Hagmann (2010) 'The geography of warscape', Third World Quarterly, 31(3), pp. 385-399; Mampilly, Rebel rulers.

${ }^{84}$ Byrne in this special issue.

${ }^{85}$ Shah, In the shadows of the state; Suykens, 'Diffuse authority'. See also, in relation to Nepal, J. Pettigrew and K. Adhikari (2010) "There is nowhere safe": Intrusion, negotiation and resistance in a hill village in central Nepal', in P. Manandhar and D. Seddon (eds) In hope and fear: Living through the People's War in Nepal. Delhi: Adroit, pp. 134-155; S. Shneiderman and M. Turin (2010) 'Negotiating Nepal's two polities: A view from Dolakha', in Manandhar and Seddon (eds), In hope and fear, pp. 200-213.

${ }^{86}$ Malik in this special issue. 
discussed thus far have a paradoxical relationship with the state. On the one hand, they are parasitic on state resources, institutions, and discourses. On the other, they all derive part of their status from the ability to transgress the order embodied by the state. Arguably all of these actors need the state as a register to replicate and transgress, an order to build on and withstand. What makes political players more-orless sovereign is the relative balance between opposing and connecting (rather than a hard-and-fast divide between those opposing and those connecting).

Even the fiercest insurgents are entangled with the state. ${ }^{87}$ In wartime Nepal, bureaucrats and other public authority figures had to navigate between state institutions and the Maoists. The insurgents would call on them to attend an event or approve a procedure. Many everyday activities required negotiation and compromise with both state and rebel governments. ${ }^{88}$ Basic ideas about what a legitimate political order looks like in a particular context are deeply engrained, even for those whose primary objective is to fight the state ${ }^{89}$ Opposing the state, in turn, is not the prerogative of insurgent groups. Goondas and political entrepreneurs are intimately connected to the state, but they derive part of their charisma from their ability to unleash violence and their intransigence towards state power. As Suykens' article on student activists in Bangladesh shows, violence may, in fact, become a way to connect to the state. ${ }^{90}$ Moreover, quite a number of actors have had to sustain themselves during the transition period, and found themselves integrating into the same state that they had earlier violently opposed..$^{91}$

Let us conclude with a particularly illustrative example, bearing on all three points discussed above, offered at the end of Thomas Hansen's

\footnotetext{
${ }^{87}$ Nel Vandekerckhove's research on Assam illustrates the peculiar patterns of negotiation, exchange, and selective contestation between rebel movements and state actors. She shows that, alongside occasional violent contestation, the more common mode of interaction in this area is in fact mutual accommodation and collaboration. Vandekerckhove, 'The state, the rebel'.

${ }^{88}$ Byrne in this special issue; Pettigrew and Adhikari, "There is nowhere safe"; Shneiderman and Turin, 'Negotiating Nepal's two polities'. See also Terpstra and Frerks in this special issue; Klem and Maunaguru in this special issue; Klem, 'In the eye of the storm'; Mampilly, Rebel rulers; Shah, In the shadows of the state; Suykens, 'Diffuse authority';

${ }^{89}$ For their notion of the state as 'the great enframer', see Hansen and Stepputat, 'Introduction', p. 27.

${ }^{90}$ Suykens in this special issue.

${ }^{91}$ Snellinger in this special issue.
} 
book Wages of violence. ${ }^{92}$ The case of Ramesh Vaiti, politician of the militia cum political party Shiv Sena, elucidates the complexities of the operation of public authority and violent contestation in South Asia. As the mayor of Thane, a city in the outskirts of Mumbai, Vaiti faced a tense situation when protests erupted over the intended prosecution of Shiv Sena leader Bal Thackeray in 2000. Angry party supporters staged protests, targeting the public representations of the state that threatened their leader. They thus turned up at the mayor's office in Thane as well, breaking windows and furniture. Faced with an attack on his own office, Vaiti-tantalizingly-joined the rioters in vandalizing the building, destroying the assets he supposedly commanded, and desecrating the institution from which he derived much of his public authority. This peculiar incident exposes Shiv Sena's more fundamental paradox of fighting against the same state with which it is deeply entangled, and it elucidates the 'unstable character of state power in India'. Hindu nationalism, more widely, emerged out of a set of cultural and religious beliefs that take issue with the dubious qualities of politics-a discursive field that Hansen calls 'anti-politics' ${ }^{93}$ _but in doing so, it produced a highly political project around a purported 'Hindu nation' under alleged threat from Muslims and secularists. ${ }^{94}$ The fascinating case of Ramesh Vaiti not only shows us the significance of violence, the crafting of subjectivity (and territory), and the paradoxical relationship with the state, it also illustrates just how quickly things can be assembled, disassembled, and reassembled. Vaiti's case strikingly illustrates the way public authority figures operate in convoluted political landscapes, with loyalties that may converge or contradict, depending on the circumstances. Sovereign forms of authority, discipline, and violence emerge out of the contingent ways in which order and disorder are enacted.

\section{Conclusion}

This introduction has laid out a fairly broad conceptual canvas for exploring the main question posed in this special issue: how is public

${ }^{92}$ Hansen, Wages of violence, p. 227.

${ }^{93}$ T. B. Hansen (1999) The saffron wave: Democracy and Hindu nationalism in modern India. Princeton: Princeton University Press, p. 12.

${ }^{94}$ See also C. Jaffrelot (2010) Religion, caste and politics in India. London: Hurst; A. Sen (2007) Shiv Sena women: Violence and communalism in a Bombay slum. London/Bloomington: Hurst/Indiana University Press. 
authority constructed in contested and violent political environments? The articles in this volume provide ethnographic explorations of how specific public authority figures operating in contested environments craft their legitimacy, reify their constituencies, and forge connections between their subjects and the state.

Straddling the literature on public authority and de facto sovereignty helps us to navigate the problematic terrain of political order and violence, which is often prone to a tendency to provide state efforts with an implicit undertone of sovereignty, normalcy, legitimacy, and indispensability, while portraying other claimants to political rule as ruthless, coercive, and disruptive problems, both in the scientific and the political sense of the word: they need to be explained and addressed. To avoid throwing away the baby (the undeniable importance of the state and the state idea) with the bathwater (the biased assumptions and categories of a statist perspective), we propose an approach that is more sensitive to questions of difference and change. Using hard categorical boundaries is unhelpful in dealing with these questions, because they disregard the manifold forms of mimicry, boundary crossing, and adaptation. There may be more parallels between rebels, politicians, goondas, bureaucrats, and community leaders than meet the eye. The line between order and disruption, or between war and peace, is thin and its production is political. The strong-arm outfits of elected politicians may be more violent and less disciplined than rebel movements. Today's militiamen may be tomorrow's politicians and vice versa, but what really changes when such a reincarnation takes place? This special issue unravels this diversity of public authority and de facto sovereignty by exploring the paradoxes, slippages, and manoeuvres. Three important overall points emerge out of the contributions to this special issue. Let us conclude by highlighting some the main observations made in the articles that follow on the basis of these three points.

Our first point concerns the role of violence in relation to public authority. Violence clearly is not simply a sign of order breaking down and authority falling short. It can also be constitutive of authority. Suykens' article on Bangladeshi student politics details how student leaders use violence to secure their connection to state institutions and resources. ${ }^{95}$ In a similar vein, Martin's work on Punjabi politics conceives of violent capacities as an extension of politics. Elected leaders deploy goondas or instigate police intervention to settle scores

\footnotetext{
${ }^{95}$ Suykens in this special issue.
} 
with opponents and instil loyalty. ${ }^{96}$ Malik's article takes this to a slightly different level. Her main protagonist-Abdur Rehman, a 'muscular sixfooter', renowned for his ability to 'take on a dozen men empty-handed'-showed his political muscle by blocking roads and using disturbance to force police officers to perform their duties. But unlike the politicians above, he did not do so to lubricate his access to the legislature (and the perks that come with it), but rather to bolster the authority of his self-declared court. ${ }^{97}$ Snellinger's article on Nepalese youth leaders in turn shows that relinquishing the means of violence does not necessarily strengthen one's position of authority. Having left behind the time of the Maoist rebellion, they now find themselves in state committees. For many, this move has muted their voice and undermined their public credentials. ${ }^{98}$

Several contributions point out that violence does not simply overrule other registers of authority. Non-sovereign actors who refrain from violent tactics do not just become puppets of supposedly more powerful actors like armed insurgents. Though groups like the Nepal Maoists or the LTTE in Sri Lanka exercised a form of de facto sovereignty, this clearly does not mean that their power was allencompassing, just like state authority does not simply trump all other forms of power. Civil servants, ${ }^{99}$ clergy, ${ }^{100}$ and community leaders ${ }^{101}$ are not merely extensions of the (de facto) sovereign orders in which they operate. They are constrained by these orders, but they nevertheless have some discretionary space-they are able to manoeuvre and cross boundaries. In doing so, they often manage to sustain their own (rudimentary) forms of public authority. The article by Klem and Maunaguru describes the challenges the LTTE faced in trying to assume control over a Hindu temple. The local priest did not have recourse to violence to counter the movement's police force or firepower, but the authority framework of the temple-with its roots in the community and the blessings of the deity-was not susceptible to the LTTE's disciplinary measures. Imprisoning the priest did not erase this moral force. ${ }^{102}$ Sen's article then brings

\footnotetext{
${ }^{96}$ Martin in this special issue.

${ }^{97}$ Malik in this special issue.

${ }^{98}$ Snellinger in this special issue.

${ }^{99}$ Byrne in this special issue.

${ }^{100}$ Klem and Maunaguru in this special issue; Terpstra and Frerks in this special

${ }^{101}$ Nightingale et al. in this special issue.

${ }^{102}$ Klem and Maunaguru in this special issue.
} issue. 
us full circle. Her contribution describes a space of unfettered sovereign power: a penitentiary holding captured Naxalite women. Without reading an undue heroism into their torturous prison life, the article brings to the fore the ability of these women to foster minimal forms of resistance and solidarity in the face of state brutality. ${ }^{103}$

Our second point highlights the significance of moral registers and cultural notions of acceptable conduct. Much of what we describe in this special issue concerns political players who tweak or break the rules of the game or rewrite them altogether. The contributions highlight a remarkable measure of creativity and innovation, transcending the bounds of state laws and institutions. At the same time, there some are remarkable forms of continuity in political practice and some fairly consistent moral boundaries as to what kind of conduct is deemed acceptable or legitimate. Nightingale et al. underline that particular patronage logics of aphno maanche (one's own people) persist through decades of drastic political transformations in Nepal: autocratic rule, democratization, war, post-war transition. ${ }^{104}$ Byrne, similarly, highlights that the improvised tactics of Nepalese bureaucrats in the war zone are not radically contingent. They are steeped in cultural registers of expectation, obligations, and prudence. ${ }^{105}$ By the same token, rebel movements articulate their sovereign rule in culturally defined idioms of power. Terpstra and Frerks' article on the LTTE reviews the symbolic ways in which the movement sought to legitimize its regime. The movement's icons, uniforms, flags, ceremonies, and cemeteries expressed a cultural lexicon that resonated with its subjects by combining familiar forms of the Sri Lankan state with an elaborate Tamil cultural repertoire. ${ }^{106}$ The case of the Pakistani workers' leader described in Malik's article resonates well with these insights. Abdur Rehman and his workers' court mustered admiration and a level of compliance, because it expressed moral norms that had been subject to erosion in the hands of the state. Beating up a man accused of molesting a girl is as much about upholding public notions of purity and morality as it is about exercising 'discipline

${ }^{103}$ Sen in this special issue.

${ }^{104}$ Nightingale et al. in this special issue.

${ }^{105}$ Byrne in this special issue.

${ }^{106}$ Terpstra and Frerks in this special issue. See also Klem and Maunaguru in this special issue. 
with immunity'. ${ }^{107}$ And, in closing this second point, it requires little elaboration that politicians in Dhaka, ${ }^{108}$ Kathmandu, ${ }^{109}$ or Punjab $^{110}$ deploy cultural icons of power and sacrifice, rituals of bonding and belonging, and cultural expressions of caste, class, or generation.

Our third and final point underscores the Janus-faced relationship that all actors featuring in this special issue have with the state. Public authority is not predetermined, nor caged in by the formal repertoire to which it appeals. It is not a simple derivative of institutional hierarchies. Rather, it is a productive force, and as such it can be remarkable malleable and adaptable. Because of this, public authority tends to be produced both by drawing from the state and by opposing it. Even the most rebellious entities are to some extent parasitic on the state: Nepal's Maoists ${ }^{111}$ and Sri Lanka's separatists ${ }^{112}$ both drew on state institutions and resources, thereby ensuring that ties were not completely severed. On the other end of the spectrum, even those agents who serve as the quotidian face of the state-bureaucrats, ${ }^{113}$ prison guards, ${ }^{114}$ elected officials ${ }^{115}$ — derive part of their potency from the ability to act in ways that are at loggerheads with the principles, rules, and institutional boundaries of the state they represent.

Public authority thus straddles the registers of how things ought to be and how things are simply done. 'A hundred per cent good man', the title of Suykens' article in this issue, 'cannot do politics'. The transgressive practices of Chatterjee's 'political society' (corruption, law-breaking, extracting favours, redirecting public goods) become entwined in normal politics. The extraordinary circumstances of war (competing sovereign formations, front lines, and shifting alliances) can become the new ordinary. ${ }^{116}$ And yet, this special issue does not conclude on a note of unbound relativism. The contributions to this volume do not suggest that 'anything goes' and supposedly 'liberal' or 'enlightened' norms of governance and legitimate order have no

\footnotetext{
${ }^{107}$ Malik in this special issue.

${ }^{108}$ Suykens in this special issue.

${ }^{109}$ Snellinger in this special issue.

${ }^{110}$ Martin in this special issue.

${ }^{111}$ Byrne in this special issue; Nightingale et al. in this special issue.

${ }^{112}$ Klem and Maunaguru in this special issue; Terpstra and Frerks in this special

${ }^{113}$ Martin in this special issue; Byrne in this special issue.

${ }^{114}$ Sen in this special issue.

${ }^{115}$ Martin in this special issue; Suykens in this special issue.

${ }^{116}$ Byrne in this special issue.
} issue. 
place in South Asia's troubled and violence-ridden landscape. On the contrary: many of the South Asians we encountered during our fieldwork were skilled political analysts. They are not naive about the political dynamics around them and needed no lesson in political science to understand the workings of power. But none of them placed their political analysis within a celebratory account of a unique South Asian politics, an idiosyncratic order that escaped the yardsticks of democracy and governance. Nightingale et al. underline that many Nepalese have, if anything, a desire for more government. ${ }^{117}$ This not only seems to hold true in the wake of civil war, but in many other parts of the subcontinent as well. Martin's article perhaps expresses this most strongly. Even when his Punjabi interlocutors saw no alternative but to approach a local big man to bypass a lethargic and obstinate bureaucracy, they realized that for many of them, the workings of 'political society' reproduced their marginality. It brought them contingent favours, rather than firm entitlements. It rendered them dispensable clients, rather than immutable citizens and ultimately, it made them precarious, rather than empowered. ${ }^{18}$

${ }^{117}$ Nightingale et al. in this special issue.

${ }^{118}$ Martin in this special issue. 